\title{
Prevalence of sexually transmitted infections among cervical cancer suspected women at University of Gondar Comprehensive Specialized Hospital, North- west Ethiopia
}

\author{
Milkias Abebe ${ }^{1 *}$, Setegn Eshetie $^{2}$ and Belay Tessema ${ }^{2}$
}

\begin{abstract}
Background: Sexually transmitted infections (STIs) such as Human Immunodeficiency Virus (HIV), Hepatitis B Virus (HBV), Hepatitis C Virus (HCV), and Syphilis have continued a significant public health problem, especially in areas with substandard infection prevention and control programs. It is known that STIs are largely associated with the increased occurrence of cervical cancer. To date, little is known about the burden of STls among cervical cancer suspected women in Ethiopia.
\end{abstract}

Objectives: To assess the seroprevalence of STIs and associated risk factors among cervical cancer suspected women with special emphasis on HIV, HBV, HCV, and Syphilis.

Methods: A hospital-based cross-sectional study was conducted among cervical cancer suspected women at the University of Gondar Comprehensive Specialized Hospital from February to April 2017. A pre-tested and structured questionnaire was used to collect data on patients' characteristics. The patient's serum or plasma samples were tested for HIV, HBV, HCV, and syphilis using enzyme-linked immunosorbent assay. In all aspects, the standard operational procedure was strictly followed. Data were analyzed using SPSS version 20 software and presented using tables. Statistical associations were measured using bivariate and multivariable logistic regression. A $p$-value of below 0.05 was considered statistically significant.

Result: A total of 403 cervical cancer suspected women with the mean age of 42.54 (SD \pm 11 . 24) years were enrolled in the study. The overall prevalence of STIs was $16.6 \%(67 / 403)$ and the prevalence of HIV, HBV, HCV, and syphilis was 36/403 (8.9\%), 10/403 (2.5\%), 4/403 (1\%), and 29/403 (7.2\%) respectively. History of multiple sexual partners (Adjusted $\mathrm{OR}=3.02,95 \% \mathrm{Cl} 1.57-5.79, P=0.001$ ), alcohol addiction (Adjusted $\mathrm{OR}=2.2,95 \% \mathrm{Cl} 1.07-4.5$, $P=0.031$ ), history of STI (Adjusted $\mathrm{OR}=3.38 ; 95 \% \mathrm{Cl}: 1.76-6.47, P=0.00$ ) and not use of condom (Adjusted $\mathrm{OR}=4.99 ; 95 \% \mathrm{Cl}: 1.5-16.16, P=0.007)$ were significantly associated with STls.

\footnotetext{
* Correspondence: mickyelfe21@gmail.com

${ }^{1}$ Department of Medical Laboratory Sciences, Institute of Health Sciences, Wollega University, P.O. Box: 395, Nekemte, Ethiopia

Full list of author information is available at the end of the article
}

(c) The Author(s). 2021 Open Access This article is licensed under a Creative Commons Attribution 4.0 International License, which permits use, sharing, adaptation, distribution and reproduction in any medium or format, as long as you give appropriate credit to the original author(s) and the source, provide a link to the Creative Commons licence, and indicate if changes were made. The images or other third party material in this article are included in the article's Creative Commons licence, unless indicated otherwise in a credit line to the material. If material is not included in the article's Creative Commons licence and your intended use is not permitted by statutory regulation or exceeds the permitted use, you will need to obtain permission directly from the copyright holder. To view a copy of this licence, visit http://creativecommons.org/licenses/by/4.0/ The Creative Commons Public Domain Dedication waiver (http://creativecommons.org/publicdomain/zero/1.0/) applies to the data made available in this article, unless otherwise stated in a credit line to the data. 
(Continued from previous page)

Conclusion: The prevalence of STIs was generally higher among cervical cancer suspected patients. Health education is encouraged to promote awareness about the prevention of STIs.

Keywords: HIV, HBV, HCV, Syphilis, Cervical cancer, Ethiopia

\section{Introduction}

Sexually transmitted infections are infections caused by pathogens that are mainly transmitted through unsafe sexual activity. They can also spread by non-sexual contact with contaminated blood, tissues, through breastfeeding, and during childbirth. Different types of bacteria, viruses, and parasites can able to cause STIs [1]. Viral STIs like human immunodeficiency virus, human papillomavirus (HPV), hepatitis B virus, and herpes simplex virus are preventable, but not treatable [2]. At present, such STIs (HIV, HBV, and HCV) has continued to be a community health problem in high, middle and low countries that causes acute illness, infertility, long-term disability, and death, with severe medical, and psychological consequences for millions of women and infants [1]. Diferrent reports showed that the prevalence of STIs related with early age of initiation of sexual activity, drug use before sex, and multiple sexual partners [3].

Thought, HPV is a necessary principal cause of cervical cancer, but it is not a sufficient cause [4]. Tobacco smoking, high parity, long-term contraceptive use, and co-infection with HIV and other STIs (syphilis, HBV, and $\mathrm{HCV}$ ), have been identified as established cofactors necessary for progression from cervical HPV infection to cancer [5]. Women infected with HIV have been shown to have a 2 to 12 fold risk of developing cervical cancer [6]. This relationship between HIV infection and HPV infection is also due to the fact that both are sexually transmitted diseases and behaviors that put women at risk for one also put them at risk for the other [6]. Co-infection with other sexually transmitted diseases (syphilis, hepatitis B virus, and hepatitis C virus) and vaginal infections are associated with increased susceptibility to HPV infection [7].

Sexually transmitted diseases, especially HIV, HBV, $\mathrm{HCV}$, and Syphilis infections are the main contributing factors for cervical cancer, which is the second leading cause of cancer death in women [5-7]. Hence, the result of the study is helpful to design a strategy for the prevention of sexually transmitted infection in cervical cancer suspected women, draw the attention of stakeholders to focus on such life-threatening but preventable infections, it also serves as a baseline data for the researchers who are interested in related topics. Therefore, this study aimed to determine the prevalence of sexually transmitted infection and its associated risk factors among women suspected of cervical cancer attending at University of Gondar Comprehensive Specialized Hospital, North-west Ethiopia.

\section{Methods}

\section{Study design, area, and population}

A hospital-based cross-sectional study was conducted among women suspected of cervical cancer from February to April 2017 at the University of Gondar Comprehensive Specialized Hospital. University of Gondar Comprehensive Specialized Hospital is one of the largest comprehensive, specialized hospitals served as a teaching as well as patient care in the Amhara region. It is located in Gondar town, $750 \mathrm{~km}$ far from Addis Ababa in Northwest Ethiopia. The hospital has an accredited laboratory, more than 1200 beds, and provides health care referral services for more than 5 million people from the surrounding zones and nearby regions [8].

\section{Inclusion and exclusion criteria}

Cervical cancer suspected women (women screened for cervical cancer who had abnormal vaginal bleeding such as inter-menstrual bleeding, post-coital bleeding) who are attending at University of Gondar Comprehensive Specialized Hospital during the study period were included in the study while patients with known STIs were excluded from the present study.

\section{Sample size and sampling procedure}

The sample size was calculated based on the assumption of 5\% expected margins of error and a 95\% confidence interval, taking the prevalence of $50 \%$ by using a single population proportion formula as follows.

$$
\mathrm{N}=\frac{(\mathrm{Z} \alpha / 2)^{2} \mathrm{P}(1-\mathrm{P})}{d^{2}}
$$

Where $\mathrm{N}$ is the calculated sample size of cervical cancer suspected women; $\mathrm{Z}$ is the standard normal deviate at $95 \%$, confidence interval $=1.96$; $\mathrm{P}$ is the prevalence of STI to get maximum sample size $=50 \%$; $d$ is the precision level $=0.05$. Then $5 \%$ contingency $=19$ were added . Finally, the total sample size $=384+19=403$ study participants.

The study participants were enrolled consecutively using a convenience sampling technique until a sample size of 403 study participants was achieved. The detailed 
information of socio-demographic characteristics, behavioral characteristics, clinical and environmental characteristics were collected prior to laboratory diagnosis from each of the study participants using structured and pre-tested questionnaires.

\section{Laboratory diagnosis}

Study participants sera was tested for the presence of sexually transmitted infection (HBV, HIV, HCV and syphilis) by using the Enzyme-Linked Immunosorbent Assay (ELISA). For HIV1/2: Vironostika ELISA (BioMerieux, Boxtel, Netherlands); Furthermore, for HBsAg: using ELISA, Hepanostika HBsAg (Bio-Merieux, Boxtel, Netherlands); Moreover, for HCV: Human anti-HCV ELISA (Human Gesellschaft for Bio-chemical and diagnostic $\mathrm{MbH}$, Germany). Besides, anti-syphilis Ab of syphilis was checked by using DIALAB ELISA (Nora Kampitsch, MSc, India). All positive participant results were sent to University of Gondar Comprehensive Specialized Hospital for the appropriate treatment.

\section{Data analysis and interpretation}

Data was collected, summarized, tabulated, and analyzed using Statistical Package Epi-Info Version7 and Statical package for social science version 20 Software. The results were presented through graphs and tables. The statistical significance, the association was measured by using bivariate and multivariate analysis, odds ratio at $95 \%$ confidence intervals. A $p$-value $<0.05$ was considered as statistically significant.

\section{Operational definition of term}

Positive STIs defined as a positive status either for single or combination of infections specific to HIV, HBV, $\mathrm{HCV}$, and syphilis.

\section{Results}

\section{Socio-demographic data}

A total of 403 cervical cancer suspected women were included in the study. The majority of the respondents were in the age groups of 36-49 years, 179 (44.4\%), and the mean age of study subjects was $42.54 \pm 11.24$ years. Nearly $70 \%$ of the participants were married, and most of the 230 (57.1\%) the participants were unable to read and write and 199 (49.4\%) of were housewives, 252 (67.5\%) of participants were from the urban (Table 1).

\section{Prevalence of sexually transmitted infection}

Among 403 cervical cancer suspected women, 67 (16.6\%) (95\% CI, 12.9-20.6) were found to be positive for STIs. Of the study participants, $36(8.9,95 \% \mathrm{CI}=6.2-11.9)$ were HIV positive, $10(2.5,95 \% \mathrm{CI}=1-4.2)$ were $\mathrm{HBV}$ positive, 4 $(1,95 \% \mathrm{CI}=0.2-2.2)$ were $\mathrm{HCV}$ positive, and 29 (7.2, $95 \% \mathrm{CI}=4.7-9.7)$ of were syphilis positive.
Table 1 Socio-demographic characterstics of cervical cancer suspected women at University of Gondar Comprehensive Specialized Hospital

\begin{tabular}{|c|c|c|}
\hline Characteristics & Frequency & Percent \\
\hline \multicolumn{3}{|l|}{ Age } \\
\hline$<=35$ years & 123 & 30.5 \\
\hline 36- 49 years & 179 & 44.4 \\
\hline$>=50$ years & 101 & 25.1 \\
\hline Total & 403 & 100 \\
\hline \multicolumn{3}{|l|}{ Marital status } \\
\hline Married & 280 & 69.5 \\
\hline Divorce & 63 & 15.6 \\
\hline Widowed & 60 & 14.9 \\
\hline Total & 403 & 100 \\
\hline \multicolumn{3}{|l|}{ Educational level } \\
\hline Unable to read and write & 230 & 57.1 \\
\hline Primary & 71 & 17.6 \\
\hline Secondary & 52 & 12.9 \\
\hline Diploma & 39 & 9.7 \\
\hline Degree and above & 11 & 2.7 \\
\hline Total & 403 & 100 \\
\hline \multicolumn{3}{|l|}{ Occupational status } \\
\hline Self employed & 15 & 3.7 \\
\hline House Wife & 199 & 49.4 \\
\hline Merchant & 47 & 11.7 \\
\hline Government employed & 46 & 11.4 \\
\hline Farmer & 96 & 23.8 \\
\hline Total & 403 & 100 \\
\hline \multicolumn{3}{|l|}{ Residence } \\
\hline Rural & 151 & 37.5 \\
\hline Urban & 252 & 62.5 \\
\hline Total & 403 & 100 \\
\hline
\end{tabular}

Of the STIs positive women, 12/67 (17.9\%) had serological evidence of multiple infections. Among those with multiple infections, 9/67 (13.4\%) were HIV- syphilis positive, $1 / 67(1.5 \%)$ were $\mathrm{HBV}$-syphilis positive, 1 (1.5\%) were HCV-HIV positive and 1 (1.5\%) were HCVsyphilis positive.

\section{Risk factors for the acquisition of sexually transmitted infections}

Firstly, bivariate logistic regression analysis was done for all study participant $(N=403)$ and variables with $P$-value $\leq 0.2$ were further tested by multivariable logistic regression analysis. History of multiple sexual partners, history of an STI, not using condoms, alcohol addiction were an independent risk factors for STI. Patients who had multiple sexual partners were three times more likely to develop STI 
compared to those who had no multiple sexual partner (Adjusted $\mathrm{OR}=3.02, \quad 95 \%$ CI $1.57-5.79, \quad P=0.001$ ). Similarly, the odds of developing STI were 3.4 times higher among patients who had a history of STI compared to the counterparts (Adjusted OR $=3.38 ; 95 \%$ CI: $1.76-6.47, P=0.00$ ). Besides patients, who had a habit of drinking alcohol were 2.2 times more likely to have STI compared to those who were not (Adjusted $\mathrm{OR}=2.2,95 \%$ CI 1.07-4.5, $P=0.031)$ (Table 2).

\section{Discussion}

The burden of sexually transmitted infections is high among cervical cancer suspected women this is due to the fact that HPV is a sexually transmitted infection and they share a common route of transmission and risk factors. This study has sought the seroprevalence of STI, HIV, HBV, HCV, and syphilis infections and contributing factors for STI among cervical cancer suspected women attending at the University of Gondar Comprehensive Specialized Hospital.
The overall prevalence of STIs in the current study was $16.6 \%$ ( $95 \% \mathrm{CI}=12.9$ to $20.6 \%$ ). The finding of this study was higher than studies conducted in Gondar which was $10.5 \%$ [9] and $11.7 \%$ in India [10]. The high prevalence of STIs among cervical cancer suspected women is due to the fact that cervical cancer-causing virus and sexually transmitted infections share a common route of transmission and risk factors.

The present study showed that the prevalence of HIV was $8.9 \%(95 \% \mathrm{CI}=6.2$ to $11.9 \%)$. It was higher compared to the study conducted in Cameroon which was $4.2 \%$ [11] and $4.1 \%$ in Nigeria [12]. The variation could be due to the fact that cervical cancer suspected women are more risk group for STIs namely HIV. An individual infected with one STIs become a high risk to be infected by HIV. Human Papilloma Virus causes inflammation around the genital area which increases the concentration of "activated" immune cells. Although the inflammatory response is meant to help fight the HPV, HIV likes to infect some of these recruited immune cells, also

Table 2 Risk factors of STIs among cervical cancer suspected at University of Gondar Comprehensive Specialized Hospital

\begin{tabular}{|c|c|c|c|c|c|c|}
\hline \multirow[t]{2}{*}{ Variables } & \multicolumn{2}{|c|}{ STIs status } & \multirow[t]{2}{*}{ COR $(95 \% \mathrm{Cl})$} & \multirow[t]{2}{*}{$P$-vale } & \multirow[t]{2}{*}{ AOR $(95 \% \mathrm{CI})$} & \multirow[t]{2}{*}{$P$-value } \\
\hline & $\operatorname{Neg}(\mathrm{N})$ & Pos (N) & & & & \\
\hline \multicolumn{7}{|c|}{ Multiple sexual partner } \\
\hline No & 197 & 20 & 1 & & & \\
\hline Yes & 139 & 47 & $3.33(1.89-5.87)$ & 0.00 & $3.02(1.57-5.79)$ & $0.001^{*}$ \\
\hline \multicolumn{7}{|l|}{ Tattooing } \\
\hline No & 126 & 18 & 1 & & & \\
\hline Yes & 210 & 49 & $1.63(0.91-2.93)$ & 0.099 & $1.05(0.54-2.03)$ & 0.9 \\
\hline \multicolumn{7}{|c|}{ History of Abortion } \\
\hline No & 244 & 39 & 1 & & & \\
\hline Yes & 92 & 28 & $1.9(1.11-3.27)$ & 0.020 & $1.5(0.79-2.85)$ & 0.217 \\
\hline \multicolumn{7}{|c|}{ Tooth extraction } \\
\hline No & 223 & 29 & 1 & & & \\
\hline Yes & 113 & 38 & $2.59(1.52-4.41)$ & 0.00 & $1.4(0.72-2.71)$ & 0.33 \\
\hline \multicolumn{7}{|c|}{ History of STI } \\
\hline No & 264 & 32 & 1 & & & \\
\hline Yes & 72 & 35 & $4(2.32-6.92)$ & 0.00 & $3.38(1.76-6.47)$ & $0.00^{*}$ \\
\hline \multicolumn{7}{|c|}{ Using Condom } \\
\hline Yes & 61 & 4 & 1 & & & \\
\hline No & 275 & 63 & $3.5(1.23-9.96)$ & 0.019 & $4.99(1.5-16.16)$ & $0.007^{*}$ \\
\hline \multicolumn{7}{|c|}{ Alcohol addiction } \\
\hline No & 148 & 14 & 1 & & & \\
\hline Yes & 188 & 53 & $2.98(1.59-5.58)$ & 0.001 & $2.2(1.07-4.5)$ & $0.031^{*}$ \\
\hline \multicolumn{7}{|c|}{ Smoke Cigarette } \\
\hline No & 307 & 54 & 1 & & & \\
\hline Yes & 29 & 13 & $2.55(1.25-5.21)$ & 0.01 & $1.34(0.51-3.56)$ & 0.55 \\
\hline
\end{tabular}


known as CD4 cells. Therefore, if someone has an STI (HPV) in the genitals and that area is exposed to HIV, the higher concentration of "activated" CD4 cells facilitates HIV infection, replication, and spread throughout the body [13]. In contrast to this; higher prevalence observed in South Africa, 14\% [14]. This may be due to differences in socio-cultural behavior.

The seroprevalence of HBV was also noted in the current study and it was $2.5 \%(95 \% \mathrm{CI}=1.0$ to $4.2 \%$ ). Comparable results were also reported in Ethiopia ranged from 3 to $3.8 \%$ [15-17]. However, the higher prevalence was reported in Gondar (4.7\%), Dessie (4.9\%), and Congo (5.9\%) [18-20]. This difference might be attributable to differences in risk for HBV acquisition and the impact of education level. In contrast to this, the lower prevalence was reported in India (0.9\%) [21] and Iran $(0.7 \%)$ [22]. The discrepancies might be a result of differences in sampling population, methodological difference, and geographical variation.

The prevalence of HCV in this study was also determined and it was $1 \%(95 \% \mathrm{CI}=0.2$ to $2.2 \%)$. The finding of this study was in line with studies conducted in the Gondar Health Center 1.3\% [9], 0.26\% North-west Ethiopia [23]. However; a higher prevalence of HCV was documented among the attendants of voluntary counseling and testing for HIV in Ethiopia 9.1, 6.0, and 4.3\% in Hawassa, Mekelle, and Adwa, respectively [24-26]. The variation is due to differences in risk behavior, sampling size, and study population. Besides, HCV infection is majorly acquired via blood transfusion other than other STIs.

Moreover, the prevalence of syphilis among cervical cancer suspected women in this study was 7.2\% (95\% CI, 4.7-9.7). The results from this study were in agreement with the report in South Africa 5\% [14], 6.4\% in North Tanzania [27], 5\% in Nigeria [12]. Studies with lower prevalence compared to our findings include; $2.3 \%$ in Gondar Health Center [9] and 2.9\% in Addis Ababa [28]. The high prevalence of syphilis among cervical cancer suspected women is due to the fact that cervical cancercausing virus and T. palladium have a common route of transmission and risk factors. On the other hand; an extremely higher prevalence $(17.4 \%)$ was reported in Cameroon [29] and 10\% in South Western Nigeria [30]. The variations could be largely due to geo-cultural differences and the decrease time trend of syphilis is also claimed in Ethiopia.

Lastly, the present study was also aimed to identify independent risk factors of STIs. The distribution of STIs was significantly higher among alcohol user women than their counterparts in the current study. In brief, patients, who had habit of drinking alcohol, were 2.2 times more likely to have STI compared to those who were not. This might be due to the fact that alcohol use is one of the common factors that lead people to exhibit risky sexual behavior and lowers a person's inhibitions, which may influence their sexual behavior, and thus a compromise safe sex practices (sex without condom) [31-33].

Additionally, the prevalence of STI was significantly higher among women who had a history of STIs $(P<$ 0.001 ) which conforms to previous studies conducted in Jimma [15] and Peru [34]. Moreover, the prevalence of STI was also significant and three times higher among the study subjects who had a history of multiple sexual partners compared to their counterparts. This is due to women who have multiple sexual partners who had a chance of getting sex with an infected person.

Furthermore, STI prevalence was five times higher among study participants who have not used condoms compared to their counterparts. Without any doubt, the condom is one of the preventive strategies against STIs. Evidently, consistent and correct use of condoms is $90 \%$ effective in reducing HIV, up to $66 \%$ effective in reducing syphilis [35]. Similarly, studies have done in New York and Southwestern China support the advantage of condoms in preventing STI [36, 37]. In this study, however, STI did not show any correlation with the history of blood transfusion, tattooing, surgical operation, smoking, and genital mutilation in the present study. This is similar to previous studies in Ethiopia [16, 38].

\section{Conclusion}

This study shows the prevalence of sexually transmitted infections was generally higher among cervical cancer suspected women. Having multiple sexual partners, not using condoms, alcohol addiction, and history of STIs found to be independent risk factors for sexually transmitted infections.

Since STIs are major health problems in cervical cancer suspected women, all cervical cancer suspected women should be screened for STIs (syphilis, HBV, HCV), increase awareness of people on modes of transmission of sexually transmitted infections and educate people how to prevent sexually transmitted infections could help in reducing the burden of STIs.

\section{Acknowledgments \\ We would like to thank all study participants.}

\section{Authors' contributions}

MA was conceived the study, designed data collection, conducted data analysis and interpretation. BT and SE interpreted the results and reviewed the initial and final drafts of the manuscript. All authors read and approved the final manuscript

\section{Funding}

Not applicable.

Availability of data and materials

All data generated or analyzed during this study were included in this article. 


\section{Declarations}

\section{Ethics approval and consent to participate}

This research was conducted after obtaining ethical clearance from School of Biomedical and Laboratory Sciences of the University of Gondar ethical review committee with reference number SBMLS/625/08. Written informed consent was obtained from Study participants after explaining the purpose and objective of the study. Any patient who was not willing to participate in the study wasn't forced to participate. All data and samples obtained from them were kept confidential by using codes instead of any personal identifiers and were meant only for the purpose of the study. The laboratory results of the study participant were communicated to their physicians for medical care. All methods were performed in accordance with the relevant guidelines and regulations in the Declaration of Helsinki.

\section{Consent for publication}

Not applicable.

\section{Competing interests}

The authors declare that they have no competing interests.

\section{Author details}

'Department of Medical Laboratory Sciences, Institute of Health Sciences, Wollega University, P.O. Box: 395, Nekemte, Ethiopia. ${ }^{2}$ Department of Medical Microbiology, College of Medicine and Health Sciences, School of Biomedical and Laboratory Sciences, University of Gondar, P.O. Box: 196, Gondar, Ethiopia.

\section{Received: 20 December 2020 Accepted: 14 April 2021}

Published online: 23 April 2021

\section{References}

1. Geremew RA, Agizie BM, Bashaw AA, Seid ME, Yeshanew AG. Prevalence of selected sexually transmitted infection (STI) and associated factors among symptomatic patients attending Gondar town hospitals and health Centers. Ethiop J Health Sci. 2017;27(6):589-600. https://doi.org/10.4314/ejhs.v27i6.4.

2. De Schryver A, Meheus A. Epidemiology of sexually transmitted diseases: the global picture. Bull World Health Organ. 1990;68(5):639-54.

3. Diclemente R, Wingood G, Sionean C, Crosby R, Harrington K, Davies S, et al. Association of adolescents' history of sexually transmitted disease ( STD ) and their current high-risk behavior and STD status. Sex Transm Dis. 2002; 29(9):503-9. https://doi.org/10.1097/00007435-200209000-00002.

4. Carlson LM, Gonzalez S. Knowledge of cervical cancer pathology of high school students in San Carlos, Costa Rica. Rev Biol Trop. 2014;62(3):877-86. https://doi.org/10.15517/rbt.v62i3.14063.

5. Smith JS, Herrero R, Bosetti C, Muñoz N, Bosch FX, Eluf-Neto J, et al. Herpes simplex virus-2 as a human papillomavirus cofactor in the etiology of invasive cervical cancer. J Natl Cancer Inst. 2002;94(21):1604-13. https://doi. org/10.1093/jnci/94.21.1604.

6. Mapanga W, Girdler-Brown B, Feresu SA, Chipato T, Singh E. Prevention of cervical cancer in HIV-seropositive women from developing countries through cervical cancer screening: a systematic review. Syst Rev. 2018;7(1): 198. https://doi.org/10.1186/s13643-018-0874-7.

7. King CC, Jamieson DJ, Wiener J, Cu-Uvin S, Klein RS, Rompalo AM, et al. Bacterial vaginosis and the natural history of human papillomavirus. Infect Dis Obstet Gynecol. 2011;2011:1-8. https://doi.org/10.1155/2011/319460.

8. Molla R, Tiruneh M, Abebe W, Moges F. Bacterial profile and antimicrobial susceptibility patterns in chronic suppurative otitis media at the University of Gondar Comprehensive Specialized Hospital, Northwest Ethiopia. BMC Res Notes. 2019;12(1):1-6 Available from: https://doi.org/10.1186/s13104-01 9-4452-4.

9. Tiruneh M. Seroprevalence of multiple sexually transmitted infections among antenatal clinic attendees in Gondar Health Center, northwest Ethiopia. Ethiop Med J. 2008:46(4):359-66.

10. Hussain T, Kulshreshtha KK, Sinha S, Yadav VS, Katoch VM. HIV , HBV , HCV, and syphilis co-infections among patients attending the STD clinics of district hospitals in Northern India. Int J Infect Dis. 2006;10(5):358-63. https://doi.org/10.1016/j.jij.2005.09.005.

11. Goh BT. Syphilis in adults. Sex Transm Infect. 2005;81:448-52.
12. Buseri F, Jeremiah Z, Seiyaboh E. Surveying infections among pregnant women in the Niger Delta, Nigeria. J Glob Infect Dis. 2010;2(3):203-11. https://doi.org/10.4103/0974-777X.68525.

13. Quinn TC, Wawer MJ, Sewankambo N, Serwadda D, Li C, Wabwire-Mangen $\mathrm{F}$, et al. Viral load and heterosexual transmission of human immunodeficiency virus type 1. N Engl J Med. 2000;342(13):921-9. https:// doi.org/10.1056/NEJM200003303421303.

14. Dinh T, Centers K, Control D, Diseases C. Integration of preventing motherto-child transmission of HIV and syphilis testing and treatment in antenatal Care Services in the Northern Cape and Gauteng Provinces, South Africa. Sex Transm Dis. 2013;40(11):846-51. https://doi.org/10.1097/OLQ. 0000000000000042

15. Awole M, Gebre-Selassie S. Seroprevalence of HBsAg and its risk factors amoung pregnant women in Jimma, Southwest Ethiopia. Ethiop J Heal Dev. 2005:19(1):45-50.

16. Zenebe $Y$, Mulu W, Yimer M, Abera B. Sero-prevalence and risk factors of hepatitis $B$ virus and human immunodeficiency virus infection among pregnant women in Bahir Dar city, Northwest Ethiopia : a cross sectional study. BMC Infect Dis. 2014;14(1):1-7.

17. Tegegne D, Desta K, Tegbaru B, Tilahun T. Seroprevalence and transmission of Hepatitis B virus among delivering women and their new born in selected health facilities, Addis Ababa, Ethiopia : a cross sectional study. BMC Res Notes. 2014;7(1):1-7.

18. Tessema B, Yismaw G, Kassu A, Amsalu A, Mulu A, Emmrich F, et al. Seroprevalence of HIV , HBV , HCV and syphilis infections among blood donors at Gondar University Teaching Hospital , Northwest Ethiopia : declining trends over a period of five years. BMC Infect Dis. 2010;10:111.

19. Seid M, Gelaw B, Assefa A. Sero-prevalence of HBV and HCV infections among pregnant women attending antenatal care clinic at Dessie referral hospital, Ethiopia. Adv Life Sci Heal. 2014;1(2):109-20.

20. Kabinda JM, Akilimali TS, Miyanga AS, Donnen P, Michèle D. Hepatitis B Hepatitis $C$ and HIV in pregnant women in the Community in the Democratic Republic of Congo. World J AIDS. 2015;5(02):124-30. https://doi. org/10.4236/wja.2015.52015

21. Dwivedi M, Misra SP, Misra V, Pandey A, Pant S, Singh R, et al. Seroprevalence of hepatitis $B$ infection during pregnancy and risk of perinatal transmission. Indian J Gastroenterol. 2011;30(2):66-71. https://doi. org/10.1007/s12664-011-0083-y.

22. Mohebbi SR, Sanati A, Cheraghipour K, Nejad MR, Shalmani HM, Zali MR. Hepatitis $C$ and hepatitis B virus infection: epidemiology and risk factors in a large cohort of pregnant women in Lorestan, West of Iran. Hepat Mon. 2011;11(9):736-9. https://doi.org/10.5812/kowsar.1735143X.1965.

23. Molla S, Munshea A, Nibret E. Seroprevalence of hepatitis B surface antigen and anti HCV antibody and its associated risk factors among pregnant women attending maternity ward of Felege Hiwot Referral Hospital , northwest Ethiopia : a cross-sectional study. Virol J. 2015;12(1):204. https:// doi.org/10.1186/s12985-015-0437-7.

24. Alemayehu A, Tassachew Y, Sisay Z, Shimelis T. Prevalence and risk factors of Hepatitis $\mathrm{C}$ among individuals presenting to HIV testing centers, Hawassa city, Southern Ethiopia. BMC Res Notes. 2011;4(1):193. https://doi. org/10.1186/1756-0500-4-193.

25. Hadush H, Gebre-Selassie S, Mihiret A. Hepatitis C virus and human immunodeficiency virus coinfection among attendants of voluntary counseling and testing Centre and HIV follow up clinics in Mekelle hospital. Pan Afr Med J. 2013;14:107.

26. Atsbaha AH, Dejen TA, Belodu R, Getachew K, Saravanan M, Wasihun AG. Sero - prevalence and associated risk factors for hepatitis $C$ virus infection among voluntary counseling testing and anti retroviral treatment clinic attendants in Adwa hospital, Northern Ethiopia. BMC Res Notes. 2016;9(1): 121. https://doi.org/10.1186/s13104-016-1936-3.

27. Kumogola Y, Slaymaker E, Zaba B, Mngara J, Isingo R, Changalucha J, et al Trends in HIV \& syphilis prevalence and correlates of HIV infection : results from cross-sectional surveys among women attending ante-natal clinics in northern Tanzania. BMC Res Notes. 2010;10:553.

28. Kebede E. And Chamiso. Prevalence of syphilis in pregnancy in Addis Ababa. East Afr Med J. 2000;77(4):212-6. https://doi.org/10.4314/eamj.v77i4.46623.

29. Mbopi Keou FX, Mbu R, Andela A, Tetanye E, Leke R, Chaouat G, et al. Antenatal HIV prevalence in Yaounde, Cameroon. Int J STD AIDS. 1998:9(7): 400-2. https://doi.org/10.1258/0956462981922485.

30. Ojo DA, Oyetunji IAO. Sero-prevalence of syphilis among pregnant women in Osogbo in South-Western Nigeria. ASSET Ser B. 2007;6(1):61-5. 
31. Regassa N, Kedir S. Attitudes and practices on HIV preventions among students of higher education institutions in Ethiopia : the case of Addis Ababa university. East Afr J Public Heal. 2011;8(2):141-54.

32. Malaju MT, Asale GA. Association of Khat and alcohol use with HIV infection and age at first sexual initiation among youths visiting HIV testing and counseling centers in Gamo-Gofa zone, South West Ethiopia. BMC Int Health Hum Rights. 2013;13(1):10. https://doi.org/10.1186/1472-698X-13-10

33. Gelibo T, Belachew T, Tilahun T. Predictors of sexual abstinence among Wolaita Sodo University Students, South Ethiopia. Reprod Health. 2013;10:18

34. Alarcon JO, Johnson KM, Courtois B, Rodriguez C, Sanchez J, Watts DM, et al. Determinants and prevalence of HIV infection in pregnant Peruvian women. AIDS. 2003;17(4):613-8. https://doi.org/10.1097/00002030-200303 070-00017.

35. Hocking JFC. Associations between condom use and rectal or urethral chlamydia infection in men. Sex Transm Dis. 2006;33(4):256-8. https://doi. org/10.1097/01.olq.0000187209.02413.0c.

36. Caico C. Sexually risky behavior in college-aged students. Open J Prev Med. 2014;4(05):354-64. https://doi.org/10.4236/ojpm.2014.45043.

37. Hu Y, Liang S, Zhu J, Qin G, Liu Q, Song B, et al. Factors associated with recent risky drug use and sexual behaviors among drug users in Southwestern China AIDS \& Clinical Research. J AIDS Clin Res. 2011;2(3):1-6.

38. Abera B, Zenebe Y, Mulu W, Kibret M, Kahsu G. Seroprevalence of hepatitis $B$ and $C$ viruses and risk factors in HIV infected children at the felgehiwot referral hospital, Ethiopia. BMC Res Notes. 2014;7(1):838. https://doi.org/10.11 86/1756-0500-7-838

\section{Publisher's Note}

Springer Nature remains neutral with regard to jurisdictional claims in published maps and institutional affiliations.

Ready to submit your research? Choose BMC and benefit from:

- fast, convenient online submission

- thorough peer review by experienced researchers in your field

- rapid publication on acceptance

- support for research data, including large and complex data types

- gold Open Access which fosters wider collaboration and increased citations

- maximum visibility for your research: over $100 \mathrm{M}$ website views per year

At $\mathrm{BMC}$, research is always in progress.

Learn more biomedcentral.com/submissions 